\title{
The Movement of Islamic Defenders Front and Its Socio Political Influence on Indonesian Society
}

\author{
Maurisa Zinira \\ Universitas Islam Negeri (UIN) Walisongo, Semarang \\ risazinira@gmail.com
}

\begin{abstract}
Abstrak
Artikel ini mendiskusikan gerakan Front Pembela Islam (FPI) di Indonesia dengan menyorot pada beberapa poin: 1) faktor dan konteks geopolitik yang mempengaruhi munculnya FPI; 2) ideologi kelompok FPI; dan 3) perkembangan FPI di Indonesia. Dalam perkembangannya, gerakan FPI sering kali menimbulkan kontroversi. Mereka mengklaim dirinya sebagai representasi kaum Muslim yang bertugas untuk memantau sekaligus memerintahkan umat Muslim untuk berbuat baik dan melarang mereka dari berbuat jahat (al-amr bi al-ma'rûf wa alnaby 'an al-munkar). Namun dalam praktiknya, mereka menjustifikasi langkah-langkah yang tidak konstitusional (seperti aksi kekerasan) demi menegakkan jargon tersebut. Di sisi lain, FPI tidak hanya keberatan terhadap kebobrokan sosial, tapi juga menentang eksistensi kelompok minoritas seperti Syi'ah dan Ahmadiyah. Dengan model gerakan takfiri, FPI secara konstan beranjak untuk mengembangkan budaya takut dalam masyarakat. Hal ini tentu menjadi tantangan serius bagi masyarakat Indonesia yang mendambakan kedamaian dan harmoni sosial. Pemerintah dalam hal ini perlu mengambil sikap yang tegas untuk melawan tindakan-tindakan intoleran melalui penegakan hukum yang serius, sekaligus menyebarkan pesan-pesan perdamaian. Jika tidak, kekuatan-kekuatan tak beradab itu akan terus berkembang dengan aksi-aksi teror yang meresahkan masyarakat.
\end{abstract}

Kata kunci: FPI, Kekerasan, Intoleransi. 


\section{Introduction}

Indonesia has been facing enormous changes after the 1998 Reformasi. After the fall of Soeharto's authoritarian regime, Indonesia has gone through flux and reflux in its process of democratization. In spite of some developments in politics and economy, Indonesia still needs to learn more democracy, especially concerning religion, over which the lives of many religious minorities are in jeopardy. Sudarto-a researcher at Bhineka Tunggal Ika National Alliance-reported that out of 2392 violent events in $2014,65 \%$ or 1554 of them, were triggered by religious factors. ${ }^{1}$ This fantastic number indicates that religious violence continues to grow. This fact also denotes that the play of religious identity is becoming stronger in public space.

Indonesia had always been a heaven for various faiths and traditions at least till 1998. Although Muslims constituted $87 \%$ of Indonesian society, there had never been such high numbers of religious violence as we have now. Various groups were living peacefully one among others and were respecting each other's beliefs, regardless of the variety of faiths and ethnicities. Irrespective of the negative effect of homogenization imposed by the Soeharto regime, national identity appeared to be strong. It can be said that "being an Indonesian" is people's first identity prior to religious and ethnic identity. But what does it mean to be Indonesian? In brief, to be Indonesian means to accept the philosophical foundation of Indonesia as a sovereign state, which is Bhineka Tunggal Ika, or unity in diversity.

But the significance of national identity diminished gradually as fundamentalism rose publicly in 1998. It is palpable that the reformasi was not only a victory for the advocates of democracy, but also for religious radicalism that used the moment to initiate religious "reform". Right after the fall of Soeharto, a group of puritan hadrami (babaib) launched publicly an organization called Front Pembela Islam (Islamic Defenders Front) henceforth known as FPI-to defend the rights of Muslims

\footnotetext{
1 Rinaldy Sofwan Fakhrana, "Agama Jadi Faktor Utama Penyulut Kekerasan", in http://www.cnnindonesia.com/nasional/20141115090933-20-11663/agama-jadifaktor-utama-penyulut-kekerasan/, accessed on April 28, 15.
} 
everywhere, particularly in Indonesia. Yet, FPI has always been a controversial movement in Indonesian society. The organization aims at becoming a moral fighter enjoining the good and forbidding wrong (al'amr bi al-ma'rûf wa al-naby al-munkar) in the society. It claims to take over the duties of putting the society in order as it claims the government failed to do. However, in the course of its development, FPI generally uses violence to stop what they call al-munkarât (evil deeds). Because of this recourse to violence, criticisms are commonly addressed to them in spite of their growing number of followers.

FPI is a consequence of the unsuccessful governing system that failed to promote civic pluralism in the society. On a larger scale, FPI also points to the crisis of Indonesia as a nation-state, its failure in managing the lives of its people in many sectors. Soeharto's failure to build effective communication with Islamists helped worsen the relationship between them and government and led to triggering Islamists to rebel against the government.

This article discusses the FPI movement, addressing its initial backdrop, its ideology and its development in Indonesia. To help the flow of the discussion, this article is systematized as follows; first, this article is outlined as the geopolitical context of Indonesia that motivated the emergence of FPI as an Islamic defenders front. In this section, it discusses how politicians took advantage of the establishment of the group to support their political agenda. Second, this article discusses FPI's ideology, its identity formation and its movement. And in the last section, I discuss how the FPI advances such ideology to Indonesian society and how it has massively changed the religious-socio-political landscape of Indonesia. Focusing my paper on the struggle of FPI as a defender of Islam, I aim to show how this movement has massively contributed to changing the face of Indonesian Islam.

\section{The Birth of Front Pembela Islam (FPI)}

There are long historical episodes of socio-political dynamics that undergird the establishment and development of FPI as an Islamist movement. There are at least four explanations of why FPI emerged. 
They include (a) failure of the national secular government to promote civic pluralism, (b) a reaction to political disenfranchisement and exclusion from democracy, (c) globalization and (d) modernization and global rise of fundamentalism.

FPI was established in August 1998 as the first Islamic group founded after the fall of New Order regime. It was initiated by a group of habâib, ustâdh and ulamâ' (mostly were from Jakarta) who gathered in alUmm Islamic Boarding School to celebrate Indonesia's independence day as well as to discuss numerous issues ranging from human right violation to political struggle, in which some Muslims claimed to have been discriminated by the secular government. ${ }^{2}$ Indeed, FPI is a reaction to the New Order's hostile policies against religion; it was established to reclaim Muslims' rights in Indonesia, which the nationalist New Order had confiscated from Muslims.

The FPI reaction represents religious-socio political grievances of many Islamists in Indonesia. Those grievances date back to the early establishment of Indonesia as a state, when Islamists and nationalists debated over the state ideology and over the management of the religion and state relationship. The religionists as represented by Mohammad Natsir argued that with Muslims being the largest population in Indonesia, Indonesia should automatically become an Islamic state to ensure accommodation to its majority inhabitants. Yet, nationalists like Soekarno argued against such a concept as it would discriminate against other non-Muslims citizens, pointing out that Indonesia had various diverse populations regarding religion, ethnicity, race and culture. ${ }^{3}$ Soekarno further suggested that religion should be a matter of private concern and should not be a final authority in determining what socalled "truth". ${ }^{4}$ However, to respond to Muslims' anxieties over protection of religion rights (from not implementing Sharia law),

\footnotetext{
2 Jajang Jahroni, Defending the Majesty of Islam: Indonesia's Front Pembela Islam, 1998-2003 (Thailand: Silkworm Book, 2008), 18.

3 Arskal Salim, Challenging The Secular State: The Islamization of Law in Modern Indonesia (Honolulu: University of Hawai'i Press, 2008), 56.

${ }^{4}$ Deliar Noer, The Modernist Muslim Movement in Indonesia, 1900-1942 (Singapore: Oxford University Press, 1973), 322.
}

248 Maurisa Zinira - The Movement of Islamic Defenders Front and Its Socio Political Influence 
Soekarno advised Muslims to increase their representatives in parliament because it would enable them to influence state policies concordant with Islamic values. $^{5}$

After a long debate on that matter, the parliament decided to not fulfill the demands of either Islamists' to establish an Islamic state or nationalists' to separate the state from religion. The result of the long debated concept of state ideology instead was the birth of PANCASILA, which enforces monotheism on Indonesian ideology. ${ }^{6}$ Nonetheless, some Islamists insisted on clear recognition of Islam as a form of state accommodation to the Muslims majority. On June 22, 1945, they insisted on the sentence "with an obligation for Muslims to implement Sharia law" into the 1945 constitutional, making it regulation for the presidential election mechanism, requiring that all candidates running for election are Muslims. But parliament vehemently opposed such insistence and refused, to insert idea of Sharia law, worrying that Christians of Eastern Indonesia would separate from Indonesia.

Outside the political debate in the parliament, those who were disappointed with their parliamentary representatives rebelled against the state. They collected themselves in a movement called Darul Islam (Indonesian Movement for an Islamic State)—led by Sekamadji Maridjan Kartosoewirjo, who attempted to establish an Islamic State regulated by Sharia law. This group grew out disappointment with the ruling regime, and was reportedly the pioneer of radical groups in Indonesia. Albeit the movement was dismantled in the 1960s following the killing of its key leaders, its network survived and spawned the biggest terrorist group in Southeast Asia—Jemaah Islamiyah.

In the next stage of Indonesia's development as a new state, the New Order regime under Soeharto used Pancasila to enforce its concept of military-based "integralism". This concept conceives state and society

\footnotetext{
${ }^{5}$ Salim, Challenging The Secular State, 56.

${ }^{6}$ Bassam Tibi, The Challenge of Fundamentalism: Political Islam and the New World Order (Los Angles: University of California Press, 2002), 49.

${ }^{7}$ Douglas Ramage, Politics in Indonesia: Democracy, Islam and the Ideology of Tolerance (New York: Routledge, 1995), 14.
} 
as an organic totality; therefore, it gives less priority to personal rights or limits on the state's power, and but puts more emphasis on social obligation. ${ }^{8}$ In support of this policy, the state held several programs on citizenship for all elements of inserting Pancasila moral values through educations. By doing so, the state expected people to know their duties as citizens and respect the role of the state in maintaining social order. Interestingly, Soeharto managed to distance the state from affinities of religion. Any mass movement (religious or non-religious alike) was therefore considered as threatening the social order, which in turn permits the state to use military action to enforce societal peace.

In spite of the relatively weak power of (Muslim) religious radicals, religious minorities under Soeharto did simultaneously experience structural discrimination. The definition of what constitutes agama (religion) and kepercayaan (belief), for instance, had made followers of indigenous religions second-class citizens in the country. This is because to have a faith considered as an agama, a belief should follow certain criteria; first, it serves as an encompassing way of life with concrete regulation; second, it should have a teaching about the oneness of God; third, it should have a holy book that codifies a message revealed to prophet(s) through a holy spirit; and fourth, it should be led by a prophet. Any faith failed that failed to meet all these criteria is henceforth called kepercayaan, which according to Ministry of Religion Decree No. 9/1952/Article VI understood as "a school of belief ...a dogmatic opinion, which is closely connected to the living tradition of several tribes, especially of those tribes that are still backward. The core of their belief is everything which has become the customary way of life of their ancestors over time". By such definition, kepercayaan is understood to be more traditional, local and superstitious. In this respect, followers of indigenous religion could not share the same privileges of good jobs and educations as the believers of agama (religion), allegedly because they were considered 'backward'.

On the other hand, under the banner of keeping order, Pancasila was also used to act against opposition primarily Islamic groups

${ }^{8}$ Ibid, 18. 
reputedly resisting Pancasila. Soeharto's secularist policies during his leadership hindered Islamists from enjoying the power. Many Islamists were frustrated at their powerlessness. In the 1980s for instance, the government restricted religious expression in public places. The regime also banned the use of religious attributes in state offices. Resistance was considered a high crime that might result in detention.

It is clear that Soeharto was extremely aware of the potential power of Muslims society. Therefore, in much of his engagement with Islam, he refused to give much room for the religion to operate beyond his control. Many Muslims were killed for being critical of government policies as the regime adamantly refused to give any space Islamists, who had supposedly endorsed the formalization of the religion-state relationship to develop their movements. ' Soeharto's hostile treatment of Muslims' political aspirations made his fall a victory for Islamists, who were able to move more freely under democracy. Islamist organization emerged virtually everywhere. FPI itself was among the first founded in 1998 as a religious civil organization aimed at struggling for Muslims' rights. With support from several national leaders and military commanders, FPI developed fast and recruited huge numbers of Muslims across Indonesia.

But the closeness of FPI and the military officials were not without political baggage. Jajang Jahroni explained that the military gave FPI a great deal of support, including money and military training. Such training was made in anticipation of emergency situation, to help military operate within society. ${ }^{10}$ One may also argue that the military approach to FPI was intended to counter criticism by left-wing groups about abuses committed by the military during the New Order regime. The military's alliance with the FPI therefore was an endeavor to deflect such criticisms and to reduce public animosity against the military. Using the rhetoric of 'Muslims generals should rule the military system', the FPI welcomed the support of the military and enjoyed the privileges it gained from the relationship. However, it is worth noting that the Muslims/military relationship is dynamic and really depends on the

\footnotetext{
${ }^{9}$ Ramage, Politics in Indonesia, 189.

${ }^{10}$ Jahroni, Defending the Majesty of Islam, 18.
} 
political situation of the moment. In today's context, their relationship is not as harmonious as it was before, partly because the FPI tends to be more violent and destructive in exercising its force, moving beyond what military officials initially expected.

In addition to the above factors, the emergence of FPI was also motivated by the rise of global fundamentalism. Fundamentalism itself is the contemporary outgrowth of tensions between the secular worldview of cultural modernity and the cultural worldview of exclusive monotheism. ${ }^{11}$ In Indonesia, Islamic fundamentalism never really had chances to demonstrate its force until after 1998. Tibi wrote:

"Clearly, Islamic civilization is characterized by great cultural diversity. During my visit to Indonesia and Malaysia in Spring 1995, I encountered Arab Muslims and even local Muslims who had studied at Al-Azhar Cairo or at Saudi universities and had thus become scripture-oriented fundamentalist in disdaining the local cultures as not truly Islamic because they are not inspired by the scripture in its original tongue; these zealots spread views infringing upon local cultures in an effort to impose upon them a neo-absolutist understanding of scriptural Arab-centric Islam. Happily, these fundamentalists in Southeast Asia are no more than an irritant at the periphery of society, and not, as their counterparts in the Middle East, a force at the center of politics."12

In 1995, Islamic fundamentalism did not pose as a great challenge for Indonesian Islam as it does now. But as religion starts gaining its power in public space, especially with the emergence of an uncivil force like FPI, the face of Indonesian Islam gradually changes.

\section{FPI's Ideology and Movement}

The emergence of FPI prefigures the growth of radical Islam in Indonesia. Since its initial establishment, FPI has performed myriad destructive actions against what they call munkarat (corruption). In 1998

\footnotetext{
${ }^{11}$ Tibi, The Challenge of Fundamentalism, 68.

12 Ibid, 49.
} 
itself, FPI reportedly mobilized crowds to fight against bandits who destroyed a mosque and local residents' houses in Ketapang, Jakarta. This tragedy led a mob of people to burn down four churches, destroy a hotel, three schools and seven houses, and kill at least thirteen people. ${ }^{13}$ This violence happened following the destruction of a mosque by a group of non-religious affiliated gangsters who were angry after a dispute over parking space. Though many parties lamented FPI's overwhelming reaction tin destroying churches and schools, FPI did not regret its behavior and refused any suggested changes in its organization. It became apparent that FPI's destructive attitude is inherent in the group's ideology in which it claims to be the defender of Islam. In fact, to know FPI is to understand more about its ideologue-Rizieq Shihab-whose understanding of Islam has been central to shaping FPI's ideology and identity.

It can be said that one cannot talk about FPI without talking about Rizieq Shihab and vice versa. Shihab is the main reference of FPI's ideology. Although it was not his initiative alone to establish FPI, Shihab has been central to the movement both as an ideologue and as the highest commander of the movement. The personality of Shihab is therefore influential for FPI, and the character of FPI take on both his identity and epistemology.

Rizieq Shihab's personality is quite unique as he maintains dual ethnicities on the same time. On one hand, he wants to preserve his hadrami ${ }^{14}$ identity, and on another hand, he maintains his Indonesian identity. As a result, Rizieq's adoption of Arab tradition, either cultural or intellectual, influences, even supports his nationalism as an Indonesian. His identity differs from that of other religious extremists in Indonesia whose nationalism has been eroded in favor of caliphate.

13 Yunita Trihandidi, "Insiden Jalan Ketapang November 1998", in http:/ / umarabduh.blog.com/2011/06/30/insiden-jalan-ketapang-november-1998/, accessed on 28 April 2015.

${ }^{14}$ Hadrami are people who come from Hadramaut, a province in South Yemen. They came to Indonesia even before colonial trading began. There is no record of their number in Indonesia since they have intermarried with the locals. 
Observing the way FPI members dress, we could easily identify similarities to Middle Eastern style of clothing, despite their pledge of loyalty to Indonesia. Shihab himself has never been seen wearing other dresses than a cloak and a turban. Though he does not condemn modern clothes, he prefers to wear modest dress since he believes that wearing such dress can preserve his inherited identity and tradition as hadramiborn. Shihab himself is a Betawi ${ }^{15}$ born from a puritan Hadrami circle. Being part of Betawi community, Shihab has been exposed to a culture that emphasizes the role of jawara/hero in community. Martial arts are part of the tradition that Betawis attempt to preserve. Therefore, it is not surprising to know that Shihab seems to be obsessed with being a moral fighter or a defender of religion through risking his life attacking many people.

Personal experience and education are determinant factors shaping Shihab's understanding of religion. He spent his elementary and secondary school years at secular institutions. He even once studied at Bethel Christian Middle School at Petamburan. He further continued his studies to SMAN 6 (state high school) and took Arabic class at LIPIA (Islamic and Arabic College of Indonesia)—a Saudi Arabia system-based institution in Jakarta in 1983. However, being perceived to be troublesome youth whose penchant was fighting, his family sent him to Saudi Arabia to continue his studies at King Saud University, majoring in Fiqh and Ushul Fiqh, and Education. Upon completion of his degree, Shihab continued his studies, taking graduate program at Universitas Antar Bangsa, ${ }^{16}$ majoring in Sharia law Malaysia. Shihab wrote a thesis titled "Pengaruh Pancasila dalam Pelaksanaan Syari'at Islam di Indonesia" (The Influence of Pancasila on the Implementation of Sharia

\footnotetext{
15 Betawi people are descendants of people living around Batavia (Jakarta) area since the $17^{\text {th }}$ century. They are a mixed ethnic group came from various parts of Indonesia as well as foreign countries mostly Arab, Chinese and Indians.

16 "Profil Habib Rizieq" in http://www.habibrizieq.com/p/profil-habib-rizieq.html/, accessed on 29 April 2015.
} 
Law in Indonesia). ${ }^{17}$ Upon completing his M.A, Shihab continued his doctoral program at the same university and wrote a doctoral dissertation titled "The Distinction of Origins and Branches of Ahl-Sunnah wa alJama'ah". ${ }^{18}$ It is then, most likely that his religious education has been influential in shaping his religious ideology and epistemology. His life in Saudi Arabia was his personal religious exposure that brought him to understanding Islam in its formalistic way. Malaysia also has been known for its Saudi Arabian style of religious education that contributed to shaping his Sharia—minded epistemology.

Rizieq Shihab's formalistic understanding of Sharia serves to be determinant factor that motivated him to conduct a da'wa focusing on al'amr bi al-ma'rûf wa al-naby 'an al-munkar (commanding righteousness and preventing corruptions). Shihab as well as FPI view Indonesian society as corrupted by the adoption of Western's values and ideologies. They believe that multidimensional crises that Indonesia encounters these days have been consequences of Indonesia's Western-affiliated politics and economics as well as the adoption of secular laws that are inappropriate for Indonesian cultures. ${ }^{19}$ The many problems faced by Indonesia are forms of God's punishment. Therefore, the only way to solve such crises is by implementing Sharia law that has been designed as guidance for Muslims' daily lives. ${ }^{20}$ Unlike other fundamentalists who propose Sharia as substitution for secular law, FPI proposes that certain ideas derived from Islamic teachings be integrated into national law. ${ }^{21}$ Adoption of Islamic law does not necessarily mean the establishment of an Islamic state because FPI believes that the Qur'an does not require Muslims to establish an Islamic state. ${ }^{22}$

\footnotetext{
17 "Habib Rizieq: Si goen Ingin Menggurui Saya dan Abu Bakar Ba'asyir tentang Iman" in http://www.arrahmah.com/read/2008/07/04/2012-habib-rizieq-si-goen-inginmenggurui-saya-dan-abubakar-baasyir-tentang-iman.html/, accessed on 29 April 2015. 18 "Profile" in http://dr-kamaluddin-nurdin.blogspot.com/p/profile.html/, accessed 29 April 2015.

${ }^{19}$ Jahroni, Defending the Majesty of Islam, 37.

${ }^{20}$ Ibid.

${ }^{21}$ Ibid., 39.

22 Ibid., 40.
} 
FPI has been very active campaigning for implementation of Islamic law. It has proposed drafts of laws against ma'siyah (transgression/disobedience), arguing that such acts have become a social disease not only within the Muslim, but also within the nonMuslim community. But what FPI means by ma'siyah is not clearly defined since FPI does not offer criteria for so-called morally good deeds. For instance, FPI not only attempts to prevent the spread of alcoholism, narcotics, pornography, prostitution, etc, but it also insists on all restaurants closing during the daytime during Ramadan, stating that such activity disrespects Muslims' worship during the month.

Being frustrated and angered by Indonesian law enforcement, FPI started using destructive and violent means to prevent what it sees as corruption (an-naby 'an al-munkar). In many occasions, FPI claims to take over government's role in combating "social disease" because the government is considered not serious in preventing the so-called social evil proliferating in society. But FPI is fully aware that its destructive actions are against the law. Therefore, before physical attack, FPI always notifies any groups it claims to have violated the law to comply with constitutional rules, otherwise, FPI will have justification to shut those institutions down. ${ }^{23}$ According to Jajang, FPI is quite procedural in executing its action. One of FPI members says:

"Illegal practices are intolerable. When the authorities respond to our notices and warnings, the problem is over. Why should we waste time and energy chartering buses and mobilizing people? We are not paid anyway. We pay them...Everything is procedural. We are good citizens. We have to stress that. If the higher authorities respond to our report and handle the problems, then the problem is over... when water is unchanneled, what happens? It floods everywhere. We can flood the city". ${ }^{24}$

In fact, FPI's destructive actions are expressions of frustration because the society they want to live in does not really exist. So violence becomes the expression of their disappointment. Violence seems the only means for FPI to send messages to its opponents to comply with

\footnotetext{
${ }^{23} \mathrm{Ibid}, 33$.

${ }^{24}$ Ibid, 35.
} 
what FPI defines as ma'ruff(good). And of course, what is understood as morally "good" is constructed. One may argue that discothèques and bars are legal, Ahmadiyya and other faith groups are protected by the state, but FPI has no concern whether these institutions are constitutionally legal. What it concerns about is the moral threat these institutions are said to bring to Muslim community.

This reminds me of Mark Juergensmeyer's thesis that violence can successfully send its message when three requirements are taken into consideration: the location where acts are committed, the time when violence is performed and the possibility for violence to reach its audience. ${ }^{25}$ Targets of violence normally are places that symbolize power of the power of the target. Therefore, since brothels, bars and cafés are perceived to be symbols of ma'siyah, FPI's attacks on them are meant to influence public's perception. FPI's control of the territory defines its public authority. ${ }^{26}$

According to Juergensmeyer, violence as an act of terrorism is meant to terrify its audiences. ${ }^{27}$ In regard to FPI's action, the attack is meant to frighten its opponents into renouncing their business. Because violence is about performance, FPI always reveals their group identity either through their dress or the face they uncover in order to convey FPI power to the public masses. Most of the time, FPI runs its patrols during Islamic holy days/months. Normally during Ramadan, after performing tarâwîh (additional prayer during the nights of Ramadan), FPI begins their activities, targeting pubs, casinos, brothels, etc. But unlike other radical groups, who always mask their face, FPI members are confident in claiming violence they perform. Apparently, FPI wants to tell the crowds the failure of the state to enforce law on social morality such as gambling, drugs, prostitution, etc. But more importantly, FPI's performance of violence is directed (mostly) to force the government to take action against munkarât (corruption).

25 Mark Juergesmeyer, Terror in The Mind of Good: The Global Rise of Religious Violence (Los Angles: University of California Press, 2003), 121-147.

${ }^{26} \mathrm{Ibid}, 134$.

27 Ibid, 5. 


\section{FPI and its Religious Socio-Political Influence in Indonesian Society}

The emergence of FPI has completely turned the face of Indonesia that has long been perceived as the model for moderate Islam, into one of the more violent Muslim societies. ${ }^{28}$ In spite of its small number, FPI has pioneered radical shift in the making of Indonesian Islam. Initially, Indonesian Islam has always emphasized on implementation of Sharia at substantial level, which is the implementation of core teachings of Islam, but such tradition has slowly eroded with the global rise of fundamentalism, under which radical group like FPI extensively demands for the implementation of Sharia at formal level, making Sharia into state laws.

In regard to religion, FPI has posed a serious real threat for religious harmony. FPI has always demanded for total disbanding of any religious movement deemed as defaming Islam, especially Ahmadiyya, which FPI perceives as a religious deviation from orthodox Islam. ${ }^{29}$ FPI often attacked Ahmadiyya communities and burnt down their mosques and houses, causing Ahmadis' displacement of the Ahmadis in in many places. It is not exaggeration to say, therefore, that FPI's action has been troublesome for many people. FPI has posed great threats to interfaith relationships, especially because FPI often uses violence as a means to send messages to its opponents.

Regrettably, government does not either at the local or the national level, seem to worry about the growth of such uncivil forces in Indonesia. Government official rather facilitate FPI demands by

28 "Religious Hostilities Reach Six Year High", in http://www.pewforum.org/2014/01/14/religious-hostilities-reach-six-year-high/, accessed on 1 May 2015.

29 Ahmadiyya is perceived as deviant because it declares Mirza Ghulam Ahmad as the last prophet after Muhammad. Though Ahmadis deny such accusation, many believe that Ahmadis have been dishonest. The same allegation is designated to Shi'ites who were said to perform taqiyya (unrevealing identity when in peril). 
disbanding Ahmadiyya movement as the way to end violence. In 2008 for instance, the government issued a joint decree signed by the Ministry of Home Affairs, the Ministry of Religious Affairs and the Attorney General's offices with support of West Java governor's office, declaring the Ahmadiyya as a deviant movement. Simultaneously, the government of East Java issued an official statement naming Shi'a as blasphemous movement, banning them from the region, and lending radical movements justification to take actions against them. These actions mark a great shift in the state-religion relationship in contemporary Indonesia. While the New Order regime often politicized religion to reinforce its power, the Indonesian government after Reformasi is rather religionized by religious leaders-successors of the Islamists who loudly campaigned for the implementation Sharia law.

Intolerant movements like FPI have long been the concern of human right defenders because the group often incites hatred and violence through its actions. In most cases, FPI triggers horizontal conflicts that end in clashes between FPI and its opponents; mostly between FPI and local people. The most recent incident happened in 2013 in Kendal - Central Java, where a mob of people burnt an FPI's car, after it accidentally killed a pedestrian as he passed by the discotheque where the FPI was patrolling. ${ }^{30}$ This incident created a public outcry against the movement. Many have called on the government to disband the organization. But it is unlikely that the government will want to do so. ${ }^{31}$

However, in spite of criticism and rejection by many people, FPI successfully attracts people to join the movement. The most conspicuous factor that supports the increased number of FPI members is its religious language that is familiar to most Indonesian Muslims.

\footnotetext{
30 The conflict started with local people who were displeased by FPI's patrol and rebuked the group, demanding them to not create tumult in their neighborhood. Their reprimand, however, was confronted by FPI, which eventually led them into a quarrel. FPI members frightened by the increased numbers of local residents, attempted to escape but accidentally killed one person from the neighborhood.

${ }^{31}$ Government refuses to ban the movement arguing that such disbanding would be undemocratic.
} 
Obligation to command righteousness and fight against evils (al-'amr bi al-ma'rûf wa al-naby 'an al-munkar) seems simple to follow for lower class urban Muslims who feel socially and religiously deprived. It is this battle against evil that Juergenmeyer calls as "cosmic war" that attracts marginalized persons to participate in such a war. They hope by such participation to be considered meaningful to society. FPI itself has been skilled in such recruitment, especially recruiting people who have experienced loss of integrity/crisis of identity. The idea of cosmic war gives them assurance about being meaningful both in this world and the afterlife. With regard to total number however, Muchsin Alatas-the current leader of FPI-claims to have seven million members across Indonesia. ${ }^{32}$ This number is actually small compared to total number of Indonesian Muslims that reaches up to 207,176,162 among the total citizenry of $237,641,326 .{ }^{33}$ Although total number of FPI supporters is relatively small, their violent activities are a huge threat for Indonesian society, especially for the future of moderate Indonesian Islam.

\section{Conclusion}

The growth of FPI is a consequence of the multidimensional crisis in Indonesia. It is the result of government's inability to accommodate the basic needs of citizens as well as to manage diversity and promote civic pluralism. FPI is also a reaction to political disenfranchisement and exclusion from democracy, globalization and modernization and to the global rise of fundamentalism.

The "Homogenization" strategy of the New Order regime made people less aware of differences. The emergence of individual identity in public space challenged the FPI and similar groups to appreciate diversity and to share public space with others. Before the 1998 Reformasi, Ahmadiyya and Shi'a were never perceived as deviant and had

\footnotetext{
32 Megiza, "Muchsin Alatas: Jumlah Kami Sudah 7 Juta" in http://www.cnnindonesia.com/nasional/20141008165430-12-5780/muchsin-alatasjumlah-kami-sudah-7-juta/, accessed on 29 April 15.

33 "Index Menurut Wilayah dan Agama yang Dianut" in http://sp2010.bps.go.id/index.php/site/tabel?tid=321/, accessed on 29 April 2015.
} 
never experienced persecution. It was only after the 1998 Reformasi, when Indonesia started exercising democracy that religious minority existence became a threat for Muslim extremists like FPI.

FPI has declared themselves representative of Indonesian Muslims and claims the right to dominate public space. It demands that Muslims occupy many strategic positions in state office to be able to implement Sharia law. Therefore, when the former vice governor of Jakarta-Basuki Tjahja Purnama-rose to governorship replacing the former governor who won presidential election in 2014, FPI held massive demonstration against Purnama's inauguration. In their speeches/orations, FPI leaders declared that their objection to Purnama was due to his religion and ethnicity as a Christian and as a Chinese descendent. FPI designated Purnama as 'kâfir' (infidel) who must be rejected as ruler of Muslims' predominant region-Jakarta. This takfir (to declare someone as 'kafir' or unbliever), according to Bassam Tibi, is an ideological weapon of Islamic fundamentalism to legitimize rejection and allows the use of violence against foes. ${ }^{34}$

Takfirism is inherent in FPI's ideology. Years before, FPI had targeted young thinkers affiliated to Jaringan Islam Liberal (Liberal Islam Network-JIL) as kâfir due to their progressive understanding of Islam. The FPI's opposition to this movement can be seen as a rejection to what Tibi calls "cultural modernity". Yet for me, FPI's stance on takfirism is also problematic because Rizieq Shihab once stated that any group willing to call others 'kafir' should be powerfully opposed. He admitted that groups like Wahhabi and Shi'a are divided into two, the moderate and the extreme. Muslims need to be firm in fighting against the extreme ones, he said. ${ }^{35}$ This, of course, shows FPI's inconsistency with regard to takfirism. Apparently, FPI does not have stable position relevant to this.

FPI is not an isolated case in itself; it rather represents the global transformation of the Muslim world. What happened in Indonesia is an impact of such global changes. Globalization has made transformations

\footnotetext{
34 Tibi, The Challenge of Fundamentalism, 99.

35 "Habib Rizieq Syihab: Perangi Syiah dan Wahabi yang Sesat" in https://www.youtube.com/watch?v=RIAkTyPKBgg/, accessed on 30 April 2015.
} 
fast. With the emergence of sophisticated technologies and Indonesian students studying at Middle Eastern universities, Middle Eastern ideologies and epistemologies are instilled in Indonesia. In Egypt, Muslim brotherhood was initially a civil movement. However, it changed its strategy, turning from a merely civil organization into political party when the dawah strategy through civil movement no longer functioned. With the similar reason, FPI possibly transforms its da'wah into political struggle because unlike other extremist groups that distance themselves from politics, FPI is not allergic to it.

FPI alone has turned the face of Indonesia's moderate Muslims society into a more radical one, but I am emphasizing that FPI symbolizes this change as it appeared publicly for the first time after the 1998 Reformasi. Throughout its operative period, FPI has frequently been criticized for being very violent and destructive. This causes many to propose that the government disband such an uncivil force from operating in the society. One may argue that such restriction violates principles of democracy since religious mass organizations like FPI do have right of free speech, however, I would rather suggest that the government rely on constitutional rule to control such uncivil movement. The government can charge the movement with criminal behavior whenever that is proven.

\section{Bibliography}

"Habib Rizieq: Si Goen Ingin Menggurui Saya dan Abu Bakar Ba'asyir tentang Iman" in http://www.arrahmah.com/read/2008/07/04L2012-habib-rizieq-si-goen-ingin-menggurui-saya-dan-abubakarbaasyir-tentang-iman.html.

"Profil Habib Rizieq" in http://www.habibrizieq.com/p/profil-habibrizieq.html.

Abduh, Umar. "Insiden Jalan Ketapang November 1998" in http://umarabduh.blog.com/2011/06/30/insiden-jalanketapang-november-1998/. 
BPS. "Index Menurut Wilayah dan Agama yang Dianut" in http://sp2010.bps.go.id/index.php/site/tabel?tid=321.

Efendy, Ratono. "Habib Rizie Shihab: Perangi Wahhabi dan Syi'ah yang Sesat" in https://www.youtube.com/watch?v=RIAkTyPKBgg.

Fakhrana, Rinaldy Sofwan. "Agama Jadi Faktor Utama Penyulut Kekerasan" in http://www.cnnindonesia.com/nasionalL20141115090933-20-11663/agama-jadi-faktor-utama-penyulutkekerasan/.

Jahroni, Jajang. Defending the Majesty of Islam: Indonesia's Front Pembela Islam, 1998-2003. Thailand: Silkworm Book, 2008.

Juergesmeyer, Mark. Terror in The Mind of Good: The Global Rise of Religious Violence. Los Angles: University of California Press, 2003.

Megiza. "Muchsin Alatas: Jumlah Kami Sudah 7 Juta" in http://www.cnnindonesia.com/nasional/20141008165430-125780/muchsin-alatas-jumlah-kami-sudah-7-juta/.

Modern Indonesia. Honolulu: University of Hawai'i Press.

Nurdin, Kamaluddin. "Profile" in http://dr-kamaluddinnurdin.blogspot.com/p/profile.html.

Pew Research Center. "Religious Hostilities Reach Six Year High" in http://www.pewforum.org/2014/01/14/religious-hostilitiesreach-six-year-high/.

Ramage, Douglas. Politics in Indonesia: Democracy, Islam and the Ideology of Tolerance. New York, NY: Routledge, 1995.

Salim, Arskal. Challenging The Secular State: The Islamization of Law in Modern Indonesia. Honolulu: University of Hawaici Press, 2008.

Tibi, Bassam. The Challenge of Fundamentalism: Political Islam and the New World Order. Los Angles: University of California Press, 2002. 